\title{
Measuring the Financial Performance of Indonesian Banking Industry Using Risk-Based Bank Rating
}

\author{
Cut Sjahrifa ${ }^{1}$, Wiwiek Mardawiyah Daryanto ${ }^{2}$, \\ Vanya Kanyaka Ananggadipa ${ }^{3}$ \\ 12 Sekolah Tinggi Manajemen Ipmi, DKI Jakarta 12750, Indonesia \\ ${ }^{3}$ School of Business and Management, Bandung Institute of Technology, DKI Jakarta 12950, Indonesia
}

\begin{abstract}
A B S T R A C T
A bank has an important role in every country including Indonesia. Bank is aimed in maintaining economic growth and national financial stability. This study is to measure and analyze the financial performance between Bank Negara Indonesia (BNI), Bank Rakyat Indonesia (BRI), Bank Mandiri, and Bank Central Asia (BCA) against the national performance condition from under Bank Indonesia's regulation No. 13/1/PBI/2011 about Banks Financial Health Assessment. The data were collected from annual report each company for the period 2012 - 2016. Furthermore, this study measure and analyze their level of financial health performance with Risk-based Bank Rating (RBBR) approach. RBBR examines NonPerforming Loan Ratio (NPL), Loan to Deposit Ratio (LDR), Current Account and Saving Account Ratio (CASA), Return on Asset (ROA), and Capital Adequacy Ratio (CAR). The result shows that those banks have a good financial performance which can be categorized in ideal and very healthy condition. The finding results will be useful for students to deepen understanding about financial ratio and for bankers to analyze and make a strategy to improve the performance.
\end{abstract}

\section{ARTICLE INFO}

\section{Financial Performance} Risk-based Bank Rating Banks Financial Assessment Indonesian Banking Industry
* Correspondent Email:

rifa.zahirsjah@ipmi.ac.id

Copyright (C) 2018 Authors. This is an open access article distributed under the Creative Commons Attribution License, which permits unrestricted use, distribution, and reproduction in any medium, provided the original work is properly cited.

\section{INTRODUCTION}

A bank is a financial institution that acts as an intermediary who accepts deposits from the public and distribute credit. Banks also aimed in supporting the implementation of national development in order to maintain economic growth and national stability. Due to their importance in the financial stability of a country, banks are highly regulated in most countries including Indonesia.

In past years, Indonesian banking industry faced a challenging period particularly in riding the business slowdown, managing bad loans (include 
a downward trend of loan growth), and an increasing rate of non-performing loans (NPL). Since the beginning of 2014, economic growth has been trending down as exports of primary commodities fell, and growth slowed in the international market, especially China. In addition, the high interest rate environment and the weakening of Rupiah had affected the domestic demands as well.

However, the decrease of business performance affected banking performance in the past 2 years. It should be noted that the uncertainties in the economy led to a smaller appetite for business expansion. But based on PricewaterhouseCoopers' Indonesian Banking Survey 2017, Indonesian bankers still clearly feels that they are in the most attractive market in Southeast Asia. So, the banks that will perform better, with more stable long-term performances will be those that are able to maintain their asset quality and liquidity, and also sustain margins.

According to Bank Indonesia's regulation that stated on No. 13/1/PBI/2011, all the Banks in Indonesia should do the self-assessment the level of financial health with Risk-based Bank Rating approach. The previous researches about financial performance is commonly to do in many industry sectors such as oil and gas, pharmaceutical, mining industry, etc. Therefore, the purpose of this study is to measure the financial performance from 2012 to 2016 between banks that included in BUKU 4 category to the national performance condition. The banks are Bank Negara Indonesia (BNI), Bank Rakyat Indonesia (BRI), Bank Mandiri, and Bank Central Asia (BCA). Abdi Dufera and his advisor Dr. Fisseha Girmay, PhD (2010) on his research project said using previous years' data of a business enterprise, trend analysis can be done to observe the percentage changes over time in the selected data.

Trend analysis is important, because with its long run view, it may point to basic changes in the nature of the business. By looking at a trend in a particular ratio, one may find whether the ratio is falling, rising, or remaining relatively constant. The research questions are (1) Who is the Bank leader that represent the national condition? (2) What is the difference of financial performance between the BNI, BRI, Bank Mandiri, and BCA?

This study is worth for students because it deepens and understand the analysis of financial ratio in the real practice. In addition, this study also important to Indonesian bankers to know the financial performance and position among the competitor, so they can analyze the situation and make astrategy to improve the performance.

\section{LITERATURE REVIEW}

\section{Development of Banking Industry in Indonesia}

Back on 1950, the Indonesian economic structure and national bank activities remained being dominated by foreign banks, while the domestic national banks playing insignificant role. Until the birth of Bank Indonesia in 1953, the Indonesian banking industry turned into an industry where all its activities were regulated by the government and Bank Indonesia.

Currently Indonesia has four categories based on the core capital that owned by the banks; BUKU 1, banks with total core capital (Tier 1) less than IDR 1 Trillion; BUKU 2, banks with total core capital (Tier 1) between IDR 1 Trillion to less than IDR 5 Trillion; BUKU 3, banks with total core capital (Tier 1) between IDR 5 Trillion to less than IDR 30 Trillion; and BUKU 4, banks with total core capital (Tier 1) between above IDR 30 Trillion.

This study only uses selected banks that included on BUKU 4 category which can represent $50 \%$ of national banking industry, starting from the loans, total third parties fund, total equity, and by all means these banks can cover majority public needs.

Table 1. Banks on BUKU 4 Category (as per December 2016)

\begin{tabular}{|c|c|}
\hline Bank & Total Core Capital (In billion IDR) \\
\hline Bank Negara Indonesia & 89,254 \\
\hline Bank Rakyat Indonesia & $136,670,139$ \\
\hline Bank Mandiri & $130,356,495$ \\
\hline Bank Central Asia & $110,246,294$ \\
\hline
\end{tabular}

Source: Annual Report 2016 each Bank 
Indonesia is in top 20 Gross Domestic Product (GDP) 2016 in the world, not surprisingly Indonesian bankers still have confident that they are in the country that has a continuous growth in the future. The survey highlights from PricewaterhouseCoopers' Indonesian Banking Survey 2017, 2016 was a more challenging year for many banks in Indonesia in comparison to past years, but bankers feel conditions are improving. While foreign banks are slightly less optimistic, half of foreign banks still believe conditions are improving and almost no banks feel conditions are worse. Based on that survey, bankers believe that demand for credit is estimated to grow strongly due to demand originating from the developing industry sectors.

Based on the table above, the Indonesian banking sector has a steady growth in the past five years. Steady but tends to decrease loan growth with compound annual growth rate (CAGR) of $10 \%$, it also occurs on third parties fund growth with CAGR $8 \%$. The CAGR is state low is because from 2014 to 2016 there was a significant decrease of growth. Whereas, Bank Indonesia targeted loan growth of
$15-17 \%$, which was later subject to revisions. CAR remains stable on healthy enough category on several years. By 2015 - 2016, the LDR dropped from very healthy into healthy category. On the other hand, Non-Performing Loans (NPL) soared to $2.05 \%$ in 2015 and $2.18 \%$ in 2016. However, the risk remains under control, reflected by CAR rate has improved for 5 straight years. Then, CASA and Time Deposits are on quite good composition in average $55 \%$ CASA and $45 \%$ Time Deposits for the last 5 years.

\section{Previous Research on Bank Performance}

According to Abdi Dufera and his advisor Dr. Fisseha Girmay, PhD (2010), Financial ratios are useful indicators of a firm's performance and financial situation. Ratio analysis involves calculation and interpretation of financial numbers by relating them in a logical manner in order to assess the strengths and weaknesses underlying the performance of an enterprise. We calculate ratios because in this way that we get a comparison that may prove more useful.

Table 2. Overall Performance Indonesian Banks 2012 - 2016

\begin{tabular}{|c|c|c|c|c|c|c|}
\hline & 2012 & 2013 & 2014 & 2015 & 2016 & CAGR \\
\hline $\begin{array}{l}\text { Total Loan } \\
\text { (in IDR Billion) }\end{array}$ & $2,707,862$ & $3,292,874$ & $3,674,308$ & $4,057,904$ & $4,377,195$ & $10 \%$ \\
\hline $\begin{array}{l}\text { Total Third Parties Fund } \\
\text { (in IDR Billion) }\end{array}$ & $3,225,198$ & $3,663,968$ & $4,114,420$ & $4,413,056$ & $4,836,758$ & $8 \%$ \\
\hline $\begin{array}{l}\text { Capital Adequacy Ratio } \\
\text { (CAR) (\%) }\end{array}$ & 17.43 & 18.13 & 19.57 & 21.39 & 22.93 & \\
\hline $\begin{array}{l}\text { Loan-Deposit Ratio } \\
\text { (LDR) (\%) }\end{array}$ & 83.58 & 89.70 & 89.30 & 91.95 & 90.50 & \\
\hline CASA / TPF (\%) & 48.94 & 54.41 & 52.84 & 54.01 & 55.33 & \\
\hline Time Deposit / TPF (\%) & 42.83 & 43.24 & 47.16 & 45.99 & 44.67 & \\
\hline $\begin{array}{l}\text { Return on Asset } \\
(\mathrm{ROA})(\%)\end{array}$ & 3.11 & 3.08 & 2.85 & 2.32 & 2.23 & \\
\hline $\begin{array}{l}\text { Non-performing Loans } \\
\text { (NPL) (\%) }\end{array}$ & 1.63 & 1.48 & 1.83 & 2.05 & 2.18 & \\
\hline
\end{tabular}

Source: Indonesian Banking Statistics (2016) 
In order to comment on the quality of a ratio one has to make a comparison with some standard or benchmark (Fabozzi, et al., 2003). The benchmark could be trend analysis or time-series analysis. In trend analysis, ratios are compared over periods, typically years. Year-to-year comparisons can highlight trends and point up possible need for action. Trend analysis works best with three to five years of ratios.

There have been a large number of empirical studies on commercial bank performance around the world (see Yeh, 1996; Webb, 2003; Lacewell, 2003; Halkos and Salamouris, 2004; Tarawneh, 2006). However, little has been done in research concentrated on multi bank to compare with national condition of its country.

\section{METHODOLOGY AND DATA}

Descriptive financial ratio was used to measure and analyze the performance between four banks (BNI, BRI, Bank Mandiri, BCA) that included in BUKU 4 category to national performance condition under Bank Indonesia's regulation. Data were collected from Annual Report each company from 2012 until 2016, Bank Indonesia regulation, and from Indonesian Banking Statistics by Otoritas Jasa Keuangan 2012 - 2016. All of these variables used are based on Bank Indonesia's regulation No. 13/1/PBI/2011 about Banks Financial Health Assessment.

According to the regulation, each bank should do self-assessment of their level of financial health performance with Risk-based Bank Rating (RBBR) approach. This method is substitute the previous assessment method which based on Capital, Asset, Management, Earning, Liquidity, and Sensitivity to market risk or well-known as CAMELS. RBRR itself use four factors to be assessed; (1) Risk Profile Factor, (2) Good Corporate Governance (GCG) Factor, (3) Earnings Factor, and (4) Capital Factor. Due to limited literature review and deepen analysis of financial ratio, in this study only examine Risk Profile Factor, Earnings Factor, and Capital Factor.

\section{The Variables and Parameters}

\section{Risk Profile Factor}

According to Bank Indonesia's regulation No. 13/1/PBI/2011, Risk Profile is an assessment of the inherent risk and the quality of risk management in Banking operations toward eight (8) basics Bank Risks: Credit Risk, Market Risk, Liquidity Risk, Operational Risk, Law Risk, Strategic Risk, Obedience Risk, and Reputation Risk. This study calculates credit risk use Non-Performing Loan (NPL) ratio and liquidity risk use Loan to Deposit (LDR) Ratio and Current Account and Saving Account (CASA) ratio.

\section{a) Non-Performing Loan (NPL) Ratio}

The sum of borrowed money upon which debtors has not made his scheduled payments for at least 90 days. A non-performing loan is either in SubStandard, Doubtful, or Loss. NPL ratio is measured using the following criteria;

$$
N P L=\frac{\text { Non }- \text { Performing Loan }}{\text { Total Credits }} \times 100 \%
$$

Non-Performing Loan is an important ratio to consider its profitability. NPL is one of the most factor which directly impact banks company, seeing the core business of this industry is distribute credit from third parties' funds. The Higher NPLs mean higher loss provision and lower profitability.

Table 3. Non-Performing Loan (NPL) Parameter Criteria

\begin{tabular}{|c|c|c|}
\hline Rank & Criteria & Category \\
\hline 1 & NPL $<2 \%$ & Very Healthy \\
\hline 2 & $2 \% \leq \mathrm{NPL}<5 \%$ & Healthy \\
\hline 3 & $5 \% \leq \mathrm{NPL}<8 \%$ & Quite Healthy \\
\hline 4 & $8 \% \leq \mathrm{NPL} 12 \%$ & Less Healthy \\
\hline 5 & $\mathrm{NPL} \geq 12 \%$ & Unhealthy \\
\hline
\end{tabular}

Source: SE Bank Indonesia No. 6/23/DPNP (2004)

\section{b) Loan to Deposit Ratio (LDR) Ratio}

LDR ratio can be used internally by the company or investors to determine the bank's short-term viability. A bank that accepts fund from third parties (Current Account, Saving Account, and Time Deposit) must have a certain measure of liquidity to maintain its operations. LDR ratio is measured using the following criteria; 


$$
L D R=\frac{\text { Total Credit }}{\text { Total Third Parties Funds }} \times 100 \%
$$

LDR ratio also can be used to assure a bank runs its initial function as an intermediary. On this ratio, Bank Indonesia applied the regulation of LDR ideal ratio is between $78 \%$ to $92 \%$.

Table 4. Loan to Deposit Ratio (LDR) Parameter Criteria

\begin{tabular}{|c|c|c|c|}
\hline Rank & Criteria & Category & Additional Information \\
\hline 1 & LDR $\leq 75 \%$ & $\begin{array}{c}\text { Not } \\
\text { Ideal }\end{array}$ & $\begin{array}{c}\text { Over of third parties' } \\
\text { funds expansion or lack } \\
\text { of credit expansion }\end{array}$ \\
\hline 2 & $\begin{array}{c}75 \%<\text { LDR } \leq \\
85 \%\end{array}$ & Ideal & $\begin{array}{c}\text { Financial intermediary } \\
\text { function runs well }\end{array}$ \\
\hline 3 & $\begin{array}{c}85 \% \text { LDR } \leq \\
100 \%\end{array}$ & $\begin{array}{c}\text { Quite } \\
\text { Ideal }\end{array}$ & $\begin{array}{c}\text { Financial intermediary } \\
\text { function still runs well }\end{array}$ \\
\hline 4 & $\begin{array}{c}100 \%<\text { LDR } \leq \\
120 \%\end{array}$ & $\begin{array}{c}\text { Not } \\
\text { Ideal }\end{array}$ & $\begin{array}{c}\text { Quite over credit } \\
\text { expansion }\end{array}$ \\
\hline 5 & $\begin{array}{c}\text { LDR }>120 \% \\
\text { Not }\end{array}$ & $\begin{array}{c}\text { Ideal } \\
\text { funds expansion or lack } \\
\text { of credit expansion }\end{array}$ \\
\hline
\end{tabular}

Source: SE Bank Indonesia No. 6/23/DPNP (2004)

\section{c) Current Account and Saving Account (CASA) Ratio}

Basically, there are three types of third parties' funds: Current Account, Saving Account, and Time Deposits. This ratio is to indicates the composition in third party funds and how much of a bank's total deposits are in current and saving accounts. The higher ratio means a larger portion on CASA instead of time deposits. Today, the ideal condition is minimum $60 \%$ of CASA and $40 \%$ of time deposits. For a bank, it is favorable to getting money in low cost (interest for debtors) to generating profit. CASA ratio is measured using the following criteria;

$$
\text { CASA }=\frac{\text { Current Account }+ \text { Saving Account }}{\text { Total Third Parties Funds }} \times 100 \%
$$

\section{Earnings Factor}

According to Bank Indonesia's regulation No. 13/1/PBI/2011, Earnings Factor is an assessment of the earnings performance, sources, and sustainability. Earnings Factor can be measured using Return on Asset (ROA) as follow;

$$
\text { ROA }=\frac{\text { Net Income }}{\text { Average Total Asset }} \times 100 \%
$$

Table 5. Return on Asset (ROA) Parameter Criteria

\begin{tabular}{|c|c|c|}
\hline Rank & Criteria & Category \\
\hline 1 & $\mathrm{ROA}>1,5 \%$ & Very Healthy \\
\hline 2 & $1.25 \%<\mathrm{ROA} \leq 1,5 \%$ & Healthy \\
\hline 3 & $0,5 \%<\mathrm{ROA} \leq 1,25 \%$ & Quite Healthy \\
\hline 4 & $0 \%<\mathrm{ROA} \leq 0,5 \%$ & Less Healthy \\
\hline 5 & $\mathrm{ROA} \leq 0 \%$ & Unhealthy \\
\hline
\end{tabular}

Source: SE Bank Indonesia No. 6/23/DPNP (2004)

Return on Asset (ROA) indicates how profitable a company is relative to its total assets. This ratio also illustrates how well management using its total assets to make a profit. The higher ROA means the company is efficient in utilizing its assets.

\section{Capital Factor}

According to Bank Indonesia's regulation No. 13/1/PBI/2011, Capital Factor is an assessment of the level of capital adequacy and capital management. Capital Factor can be measured using Capital Adequacy Ratio (CAR). If the result of CAR ratio achieving above 14\%, means the banks have a systemic impact. So, if the banks who have a systemic impact collapse, it will directly affect the Indonesian economy. Those banks required to have a higher capital reserve. CAR ratio is measured using the following criteria;

$$
\text { CAR }=\frac{\text { Tier } 1 \text { Capital }+ \text { Tier } 2 \text { Capital }}{\text { Risk Weighted Assets }} \times 100 \%
$$

Table 6. Capital Adequacy Ratio (CAR) Parameter Criteria

\begin{tabular}{|c|c|c|}
\hline Rank & Criteria & Category \\
\hline 1 & CAR $>12 \%$ & Very Healthy \\
\hline 2 & $9 \% \leq \mathrm{CAR}<12 \%$ & Healthy \\
\hline 3 & $8 \% \leq \mathrm{CAR}<9 \%$ & Quite Healthy \\
\hline 4 & $6 \%<\mathrm{CAR}<8 \%$ & Less Healthy \\
\hline 5 & CAR $\leq 6 \%$ & Unhealthy \\
\hline
\end{tabular}

Source: SE Bank Indonesia No. 6/23/DPNP (2004)

Capital Adequacy Ratio (CAR) is the ratio of a bank's capital to its risk. Regulator track a bank's CAR to ensure that it can absorb a reasonable amount of loss and complies with statutory capital requirements. 


\section{RESULTS AND DISCUSSION}

1. Risk Profile Factor

a) Non-Performing Loan (NPL) Ratio

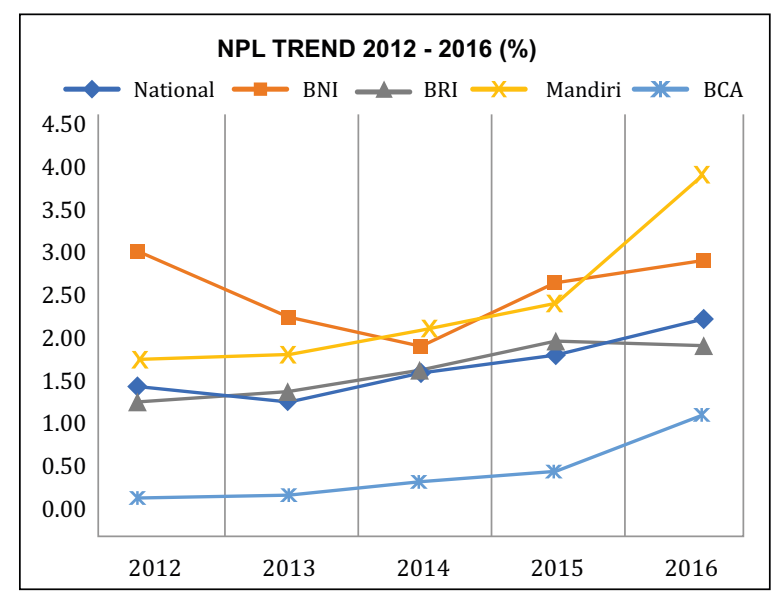

Figure 1. Non-Performing Loan (NPL) Trend

From figure 1. denotes that from 2012 until 2014, the national condition remains stable means that cumulative of all banks in Indonesia can maintain the ratio under $2 \%$ (very healthy). Whereas on 2015 and 2016, the ratio was increase to above $2 \%$ (healthy). If compared with the national condition, BNI and Mandiri is above the line and have a significant increase of NPL. It will be eroded bank's profitability. The figure 1 also shows that BCA has the most stable and well managed the NPL ratio under $1.5 \%$ in the past 5 years. However, all banks have a good achievement because their results are still on very healthy and healthy categories.

\section{b) Loan to Deposit Ratio (LDR) Ratio}

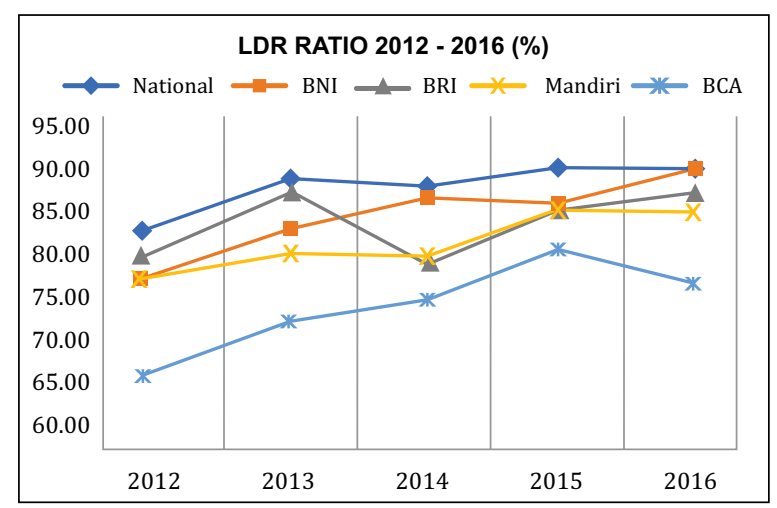

Figure 2. Loan to Deposit Ratio (LDR) Trend

The figure 2. shows information about liquidity risk performance under LDR ratio. The figure also shows that BNI and BCA are good at maintaining the stability of their LDR. However, BCA still has fund laxness to do a credit expansion. Since Bank Indonesia applied the regulation of LDR ideal ratio is between $78 \%$ to $92 \%$, overalls, the national condition and all banks have a good ratio of LDR.

Certainly, these banks are running their function well as a financial intermediary who accepts deposits from third parties and distribute credit to business sector. Bank Indonesia also applied the regulation that $8 \%$ from LDR ratio as a statutory reserve, if the ratio exceeds $92 \%$ it means the $8 \%$ is taken from non-third parties fund for credit expansion. It indicates the banks is over in giving a loan or cannot fulfilling third parties' funds, so they should take from non-third parties fund such as issuing bonds.

\section{c) Current Account and Saving Account (CASA) Ratio}

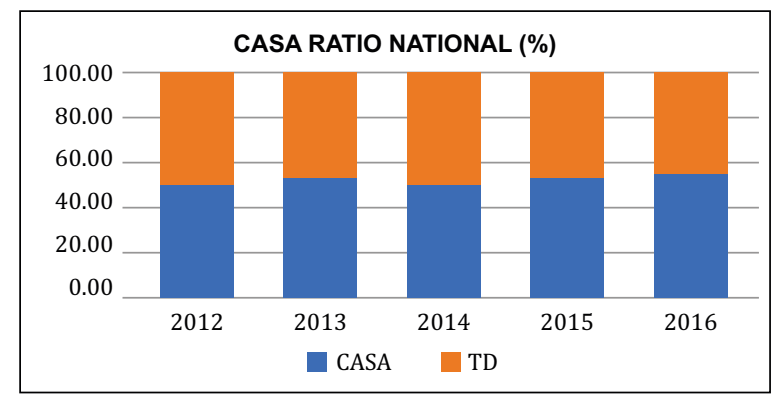

Figure 3. Current Account and Saving Account (CASA) National Trend

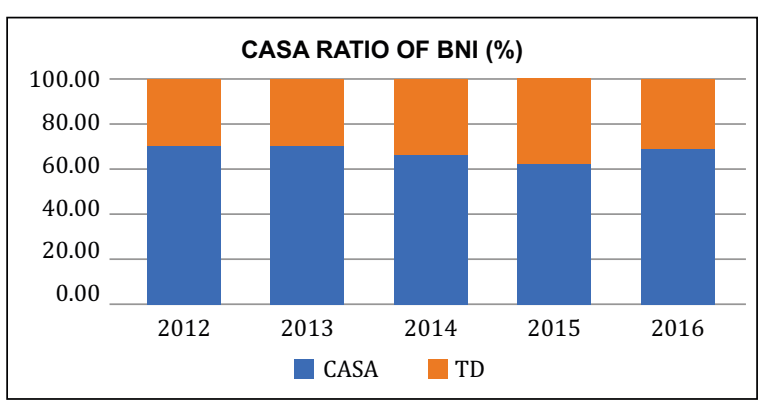

Figure 4. CASA BNI Trend

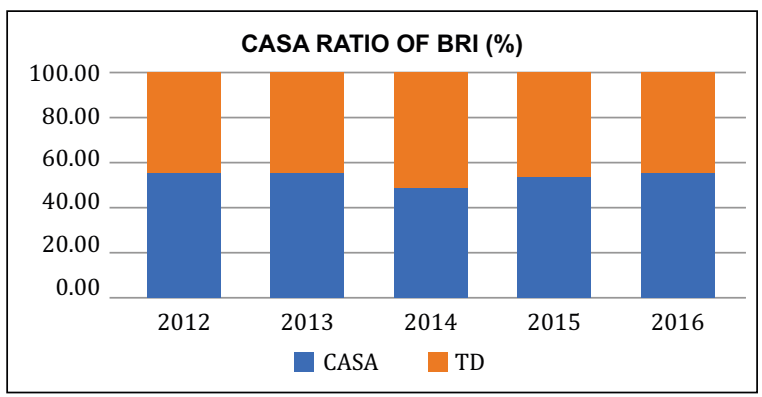

Figure 5. CASA BRI Trend 


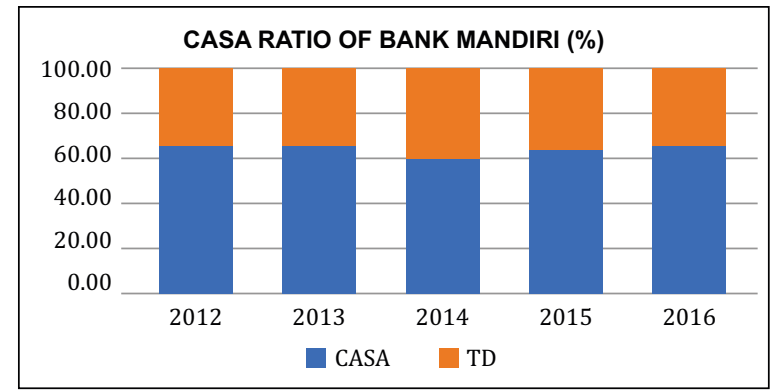

Figure 6. CASA Bank Mandiri Trend

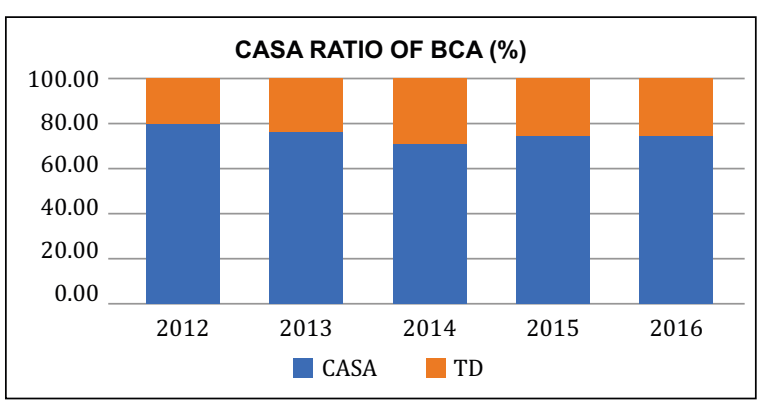

Figure 7. CASA BCA Trend

From all figures above denote that for the national condition, composition for third parties' funds are in average for 5 years 55\% CASA and 45\% Time Deposits. Overalls, all banks show the good ratio of CASA, but the highest ratio between four banks is BCA in average 77\% CASA and 23\% Time Deposits. This composition affects cost of fund which will impact on banks' profitability measured by Net Interest Margin (NIM).

\section{Earnings Factor}

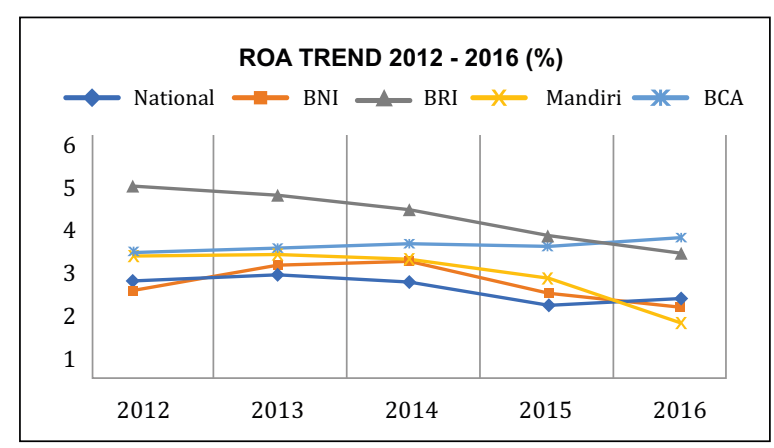

Figure 8. Return on Asset (ROA) Trend

The figure 8. denotes there are a decrease trend in all banks except BCA for the last five years. A decreasing ROA might be caused by the business slowdown and a decreasing growth in loan from 2012 . However, if the result is above $1.5 \%$ means the financial performance of the company is very healthy. Based on ROA's result, BCA is more stable in efficiency in utilizing their assets to make a profit.

\section{Capital Factor}

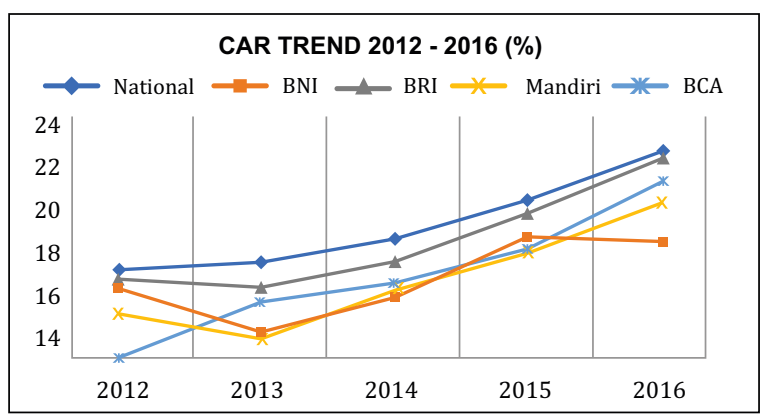

Figure 9. Capital Adequacy Ratio (CAR) Trend

The figure above shows the percentage of the level of capital adequacy and capital management. It also shows that BRI has the highest result of CAR for five years and be the closest bank on total capital with the national condition. However, all banks have CAR ratio above $14 \%$ meaning the banks in BUKU 4 are very healthy and have a systemic impact.

\section{LIMITATION}

This study is only examined several ratio and basic bank risks based on Risk-based Bank Rating (RBBR). RBBR required four factors to be determined and each factor has its own ratio. This study only focuses on three factors except the Good Corporate Governance (GCG) factor.

In near future, it is suggested to expand the literature about financial performance in banking or other industry. It also suggested to examine the GCG factors to complete the analysis for 8 basic bank risks.

\section{CONCLUSION AND RECOMMENDATION}

The purpose of this research is to measure the differences of financial performance between the BNI, BRI, Bank Mandiri, and BCA against the national condition using Risk-based Bank Rating (RBBR) method in the last five years (2012 - 2016). The research found that the financial performance of those banks is good and include in ideal and very healthy condition especially in CAR, LDR, and ROA. Since all banks have a systemic impact, there was no significant result that pointed to one bank to be a bank leader that represent the national condition. All of them represents more than $50 \%$ 
of national financial performance although there was a slightly decline caused by a slowdown growth of business.

However, from the results on this study, the banks should more manage the stability of their NPL and CASA ratio in order to gain more profitability. In 2015 and 2016, the ratio of all four banks and is getting higher that soared above $2 \%$. It also happens with the national performance. NPL is one of the most factor which directly impact banks company, seeing the core business of this industry is distribute credit from third parties' funds. When the NPL increase, it will erode the bank' profit. In line with NPL ratio, the ratio of CASA should manage in good composition. The higher CASA is better, because it also impacts on banks' profitability which can be measured by Net Interest Margin (NIM).

\section{REFERENCES}

Bank of Indonesia (2004). Surat Edaran Bank Indonesia No.6/23/DPNP: Sistem Penilaian Tingkat Kesehatan Bank Umum dan Lampiran. Retrieved from http://www.bi.go.id/id/peraturan/perbankan/Pages/ketentuan\%20perbankan.aspx

Bank Indonesia. (2011). Peraturan Bank Indonesia Nomor: 13/ 1 /PBI/2011 Tentang Penilaian Tingkat Kesehatan Bank Umum. Retrieved September 22, 2017 from

http://www.bi.go.id/id/peraturan/perbankan/Documents/828aa23594154a89aeabab7dc31038 05pbi_130112.pdf

Bursa Efek Indonesia. (2013). BBCA Annual Report 2012 - 2016. Retrieved from http://www.idx.co.id Bursa Efek Indonesia. (2013). BBNI Annual Report 2012 - 2016. Retrieved from http://www.idx.co.id Bursa Efek Indonesia. (2013). BBRI Annual Report2012 - 2016. Retrieved from http://www.idx.co.id Bursa Efek Indonesia. (2013). BMRI Annual Report2012 - 2016. Retrieved from http://www.idx.co.id Dufera, A. (2010). Financial Performance Evaluation. A Case Study of Awash International Bank (AIB). Retrieved from https://opendocs.ids.ac.uk/opendocs/bitstream/handle/123456789/5226/Financial\%20Performance\%20Evaluation.pdf?sequence $=1$

Fabozzi, F. J., \& Peterson, P. P. (2003). Financial management and analysis (Vol. 132). John Wiley \& Sons.

Global Business Guide Indonesia. (2016). Indonesia's Banking Sector; Under Pressure but Staying Strong. Retrieved from http://www.gbgindonesia.com/en/finance/article/2016/indonesia_s_banking_ sector_under_pressure_but_staying_strong_11409.php

Investopedia. Capital Adequacy Ratio - CAR. Retrieved from http://www.investopedia.com/terms/c/capitaladequacyratio.asp

Investopedia. Current Account, Savings Account (CASA). Retrieved from http://www.investopedia.com/terms/c/current-account-savings-account.asp

Junaeni, I. (2016). Tingkat Kesehatan Bank Berdasarkan Risiko (Risk Based Bank Rating - Rbbr). Retrieved from https://dosen.perbanas.id/tingkat-kesehatan-bank-berdasarkan-risiko-risk-based-bankrating-rbbr/

Otoritas Jasa Keuangan. (2013). Statistik Perbankan Indonesia 2012 - 2016. Retrieved from http://www.ojk.go.id/id/kanal/perbankan/data-dan-statistik/statistik-perbankan-indonesia/ Default.aspx 
Cut Sjahrifa, Wiwiek Mardawiyah Daryanto, Vanya Kanyaka Ananggadipa / Measuring the Financial Performance of Indonesian Banking Industry Using Risk-Based Bank Rating/33- 41

Price water house Coopers. (2015). Indonesian Banking Survey 2015. Retrieved from https://www.pwc.com/id/en/publications/assets/banking-survey-2015.pdf

Price water house Coopers. (2017). Indonesian Banking Survey 2017. Retrieved from https://www.pwc.com/id/en/publications/assets/financialservices/ibs-2017.pdf

Statistic Times. (2016). List of Countries by Projected GDP. Retrieved from

http://statisticstimes.com/economy/countries-by-projected-gdp.php

Tarawneh, M. (2006). A comparison of financial performance in the banking sector: Some evidence from Omani commercial banks. International Research Journal of Finance and Economics, 3(3), 101-112. 